\title{
The contest determinant of delight and disappointment: the case study of online banking
}

Purpose: This study considers perceived online service quality and online service recovery as antecedents to online satisfaction for the purposes of investigating which factor has the most significant impact on online customer satisfaction and loyalty.

Design/methodology/approach: An online questionnaire method approach was used to survey 428 customers of online banking (123 of whom reported a service failure). Exploratory factor analyses, oblique rotation and varimax rotation were used to assess scale validity. The hypotheses were tested using structural equation modeling based on partial least square (PLS) and bootstrapping analysis.

Results: Perceived service quality and service recovery have direct/indirect effects on customer loyalty through customer satisfaction. The mediating role of satisfaction was also confirmed. Rather than service recovery, e-quality is the most important predictor of customer satisfaction and loyalty

Management implication: Antecedents such as online service quality, service recovery and satisfaction can be used to forecast customer loyalty in e-banking. However it is more important to increase customer satisfaction, which requires placing an external focus on developing what will "go right" in the first place by enhancing online perceived service quality, instead of preventing dissatisfaction through recovery, which is an internal focus on fixing what has "gone wrong"

Original value: This study is the first to provide important insights into both the direct and indirect impacts of e-service quality and e-service recovery on building relationships characterized by customer satisfaction and loyalty. As well as providing definitive evidence in terms of the various sub-dimensions of service quality and service recovery.

Keywords: Electronic service quality; electronic service recovery; customer satisfaction; customer loyalty 


\section{INTRODUCTION}

The Web has become ubiquitous and the internet retail market is growing at an exponential rate. In addition, search engines and comparison websites are commonly used for product evaluation and selection, and customers are increasingly eager to share experiences through social media. Thus online service providers have to deal with more and more clued-up customers. Acquiring online consumers is difficult and costly, since the high overheads of securing new online customers can cause loss-making customer relationships for up to three years (Reichheld and Schefter, 2000). In such a competitive environment, creating a base of loyal customers is of paramount importance.

Although it was evidence that repeat purchases is a major predictor of customer loyalty and eventually profitability (Marimon et al., 2010), few companies appear to thrive in building loyalty, and the strategy in engendering customer loyalty in e-service is fuzzy (Ribbink et al., 2004). Since, the relationship between service quality and loyalty and the moderating role of perceived value and satisfaction have been firmly advocated (Anderson \& Srinivasan, 2003; Parasuraman et al., 2005; Petnji et al., 2011; Chen and Cheng, 2012; Chang et al., 2012). However, the universality of this relationship remains questionable (Ribbink et al., 2004), since earlier studies in online contexts are not consistent. For example, the well-established quality-satisfaction-loyalty chain was not supported in one of the online services studied by Harris and Goode, (2004).

Likewise, a growing body of extant literature has shown service quality and service recovery to be related to customer loyalty in different ways. It was shown quality is only indirectly related to loyalty via perceived value and satisfaction (Caruana, A. 2002; Akinci et al., 2010, Liang, 2012; Marimon, et al., 2012), and recovery directly predicted loyalty (Parasuraman et al., 2005; Boshoff, 2005; Lin, 2012). The question that then arises for e-commerce is the extent to which loyalty depends on online service quality or the extent to which it depends on online service recovery, particularly while considering the mediating effect of online satisfaction.

Furthermore, it has been argued that service recovery plays a key role in any service management tactic (Boshoff, 2005). As it was reported that customers who experience service 
failure typically discuss the incident with 10 other persons, while those not experiencing failure only tell 5 other persons about their positive experience (Oliver, 2010). Besides, few attempts have been made to scrutinize empirically the role of service recovery in customer satisfaction and loyalty. This is perhaps because it is a very new concept, or it is difficult to investigate due to the limited samples of customers who have used the system and had non-routine encounters (Parasuraman et al., 2005; Ladarhi, 2010). For whichever reason, little is known about customer behavior with regard to service recovery. The main objective of this study is therefore to try to take a further step in understanding the antecedents of customer loyalty, by:

- proposing and testing an integrated model that may shed some light on the strength of the impact of e-quality and e-recovery on online satisfaction;

- assessing the direct and indirect effects of e-service quality and recovery on loyalty with satisfaction as a mediator, in addition to the direct effect of satisfaction on loyalty; assessing whether it is more important for satisfaction and loyalty to get things right the first time (e-quality), or to succeed in solving the problems subsequently (e-recovery).

The remainder of this paper is organized as follows. Extant literatures on the topic are briefly described, and hypotheses are developed with regard to the relationships that incorporate online service quality, online service recovery, satisfaction, and loyalty. Thereafter, we describe a conceptual framework summarizing the hypotheses. Then, we describe the methodology used and presented our results. Finally, we closed with major conclusions and management implications.

\section{LITERATURE REVIEW AND CONCEPTUAL FRAMEWORK}

\subsection{Perceived online service quality as an antecedent of customer satisfaction}


According to Parasuraman et al., (1988), perceived service quality can be defined as the outcome measure of the gap between customers expected performance of service offered and its perceptions of the level of service received, whereas customer satisfaction can be described as customers' evaluations of a product or service with regard to their needs and expectations (Oliver, 1993). Unequivocally ambiguous opinions have however been expressed in the existing literature regarding the conceptual association between service quality and customer satisfaction (Cronin and Taylor, 1992). Despite the fact that there is no clear consensus on the causal order in the link between perceived service quality and satisfaction, both concepts have generally been perceived as distinct constructs. For example according to the study conducted by Parasuraman et al. (1988), customers perceived service quality as a long-term overall judgment of service delivery, and customer satisfaction as a transaction-specific judgment. This distinction is important to both managers and researchers, since service providers need to know whether their objective should be to have consumers who are satisfied with their performance or to deliver the maximum level of perceived service quality (Sprenc and Mackoy, 1996).

Conversely, the causal link from perceived service quality to customer satisfaction model appears to be commonly accepted. Zeithaml and Bitner (2000), for example, argued that service quality evaluation mainly emphases on dimensions of service, and that perceived quality is not only a constituent of customer satisfaction but is also inclined by other factors such as product quality, price and other customer features. Besides, satisfaction appears to be a broader, more inclusive concept that is based upon perceived service quality and other factors (Oliver, 1993). Given that customers do not principally purchase the superior quality service, but may also take into account situational factors such as price, convenience, and availability that may directly impact on satisfaction while not having an influence on customers perceived service quality (Cronin and Taylor, 1992). Furthermore, Petnji et al., (2011) and Liang, (2012), advocated that perceived service quality should be treated as an antecedent of satisfaction. It was therefore anticipated that: 
H1: online perceived service quality directly and positively affects online satisfaction (where perceived service quality consist of (a) Efficiency, (b) System Availability and (c) Privacy)

\subsection{The relationship between online service recovery and customer satisfaction}

Similarly, research has repeatedly shown that recovery efforts are crucial for building and maintaining lifelong relationships with customers. Given that there is a growing body of empirical evidence that upholds that satisfactory service recovery is linked to customer loyalty, commitment, trust, and other valuable outcomes, such as positive word-of-mouth, retention, value, enhanced perceptions of the firm's competence, and satisfactory image in terms of perceived service quality (Tax, Brown \& Chandrashekaren, 1998; Boshoff, 2005; Parasuraman et al., 2005; Lin, 2012).

While online retail continues to thrive and the volume of online service encounters continues to increase rapidly, failures are nevertheless still a common occurrence in online service offer (Marimon et al., 2012). Hitherto, few online service providers have really determined the precise nature of satisfaction of unhappy customers after the hard work of service recovery has been finalized. Thus online service providers are oblivious to the damage caused by poor recovery, simply because there is no assessment of customer satisfaction with service recovery (Boshoff, 2005). Research into this issue has not gone far enough to determine the negative effects of recovery on satisfaction and how they can be dealt with. This is particularly alarming if one considers that online service firms' responses can be highly variable and that only about half the total number of service failure complaints are satisfactorily addressed (Estelami, 2000).

It is clear that a failure to ensure customer satisfaction through service recovery could lead to a decline in customer confidence, lost customers, negative word-of-mouth, possible negative publicity, and the direct cost of re-performing the service (Berry and Parasuraman, 1991). Moreover, a failure to ensure that complaining customers are satisfied with the online firm's service recovery efforts can only lead to serious problems, since the online service firm will be running the risk of letting the customer down for a second time (Boshoff, 2005). Online service 
failures may attach negative attributions to the product or service offer, but a proportionate response in terms of good service recovery can reduce these negative attributions and produce a positive upshot of a kind that may lead to a higher level of satisfaction. Consequently online service providers have a large ante in understanding how to provide an effective recovery, so that they can curtail customers' dissatisfaction. It was therefore anticipated that:

H2: online service recovery directly and positively affects online satisfaction (where service recovery consist of (d) Responsiveness and (e) Contact)

\subsection{The impact on customer loyalty}

Some authors have emphasized the need to examine how to increase loyalty levels and the internet consumer acquisition decision (Parasuraman et al., 2005; Chen and Cheng, 2012; Sousa and Voss, 2012). Obviously, understanding these antecedents can help online service provider to gain a competitive advantage by implementing specific strategies to increase loyalty which in turn will enhance business performance; particularly in the context where online service consumers are becoming more and more knowledgeable and are willing to share their experiences through social media. Besides, it was reported that positive messages in online discussion forums may affect consumers' decisions to shop online (Lee et al., 2011)

Indeed, various studies appear to show an emerging consensus that customer satisfaction is a key determinant of customer loyalty. For example, Bloemer et al. (1999) state that the precise nature of the interaction between customer satisfaction and loyalty is especially vague, but that satisfaction would seem to have a positive influence on service loyalty. Fornell (1992) found that high satisfaction results in customers with increased loyalty and less prone to be receptive to approaches from the competition. Anderson and Sullivan (1993) established that satisfied customers have a greater propensity to be retained and to resist alternative options. Petnji et al. (2011) state that perceived e-service quality positively affects customer satisfaction and loyalty. It emerges from a review of past research not only that the idea of satisfying customers has a clear 
common-sense appeal, but that it is also generally believed that customer satisfaction leads to loyalty and translates into higher future profits (Dahlsten, 2003). Therefore we hypothesized that:

H3: customer satisfaction directly and positively affects customer loyalty

In the same vein, most studies indicated that perceived online service quality has direct/indirect positive effects on loyalty in the context of e-commerce (Parasuraman et al., 2005; Akinci et al., 2010; Sousa and Voss, 2012; Chen and Cheng, 2012). Service quality has become a great differentiator and the most prevailing competitive weapon which many leading service organizations possess (Zeithaml et al., 2002). Prior research has scrutinized the effectiveness of online service quality in influencing customer loyalty. The extant literature strongly supports the hypothesis that there is a positive relationship between service quality and recommendation, and resistance to better alternatives, jointly identified as an emotionally-motivated pattern of behavior in a context of intentional customer loyalty. Additionally, Marimon et al. (2010) argued that there is a positive relationship between perceived service quality and repurchase intention, thus capturing the attitudinal part of loyalty. Therefore in a competitive e-commerce environment, an offensive marketing strategy is essentially determined by the online provider's ability to expand and maintain a large and loyal customer base. Hence, delivering superior service quality to customers is a key determinant in the formation of customer loyalty (Parasuraman et al., 1988). We therefore hypothesized that:

\section{H4: online perceived service quality directly and positively affects customer loyalty}

Furthermore, effective service recovery is essential because online customers are difficult to attract and retain, and it is easy for them to switch to other online providers (Reichheld \& Schefter, 2000). It is therefore extremely important that service providers on the Internet know how to improve loyalty levels and to encourage repeat purchasing decisions among their customers (Tax, Brown \& Chandrashekaren, 1998; Estelami, 2000; Boshoff, 2005; Parasuraman et al., 1991, 1998, 2005; Marimon et al., 2012). Effective service recovery plays an important role 
in ensuring such loyalty. Of course, it is preferable that e-providers deliver a service without failures because, in general, providers fare better in the eyes of consumers by avoiding service failure than by responding to failure with superior recovery (McCollough et al., 2000; Marimon et al., 2012). However, when a failure has occurred, effective service recovery is considered essential to business survival in general (Berry \& Parasuraman, 1991), and in the context of ecommerce in particular (Reichheld \& Schefter, 2000). Therefore we hypothesized that:

\section{H5: online service recovery directly and positively affects customer loyalty}

There is a widespread acceptance that customer-perceived online service quality is an antecedent of customer satisfaction, which in turn is a key determinant of customer loyalty (Petnji et al., 2011). Yet, although the relationship between satisfaction and loyalty seems almost intuitive, it has been found to vary significantly in different conditions (Anderson \& Srinivasan, 2003). For example, in the traditional services, it has been argued that customer satisfaction performs a mediating role in the link between service quality and customer loyalty, and that 53 percent of customer satisfaction variance is explained by service quality (Caruana, 2002). Consequently, customer satisfaction may be important, but it cannot explain all the variance of customer loyalty (Chiou, 2003). Conversely, the well-established quality-satisfaction-loyalty chain was not supported in one of the online services studied (Harris and Goode, 2004).

Moreover, extant research has investigated the direct/indirect effects of service recovery in relation to loyalty models with value as a mediator (Parasuraman et al., 2005; Akinci et al., 2010; Marimon et al., 2012). Nonetheless, few attempts have been made to examine empirically the mediating role of satisfaction in the link between service recovery and loyalty, prompting calls for broader frameworks that involve the simultaneous effects of online service quality, online service recovery and customer satisfaction on loyalty. To this end, this study also intends to examine the mediating role of customer satisfaction on the direct links between customer-perceived online service quality, online service recovery and customer loyalty. 
In order to further the preceding review and discussion, a model that identified the key constructs included in this research is provided in Figure 1. The framework presents loyalty as a consequence of direct/ indirect relationships with service quality, recovery and satisfaction.

Figure 1: Research Model

Figure 1: Research Model

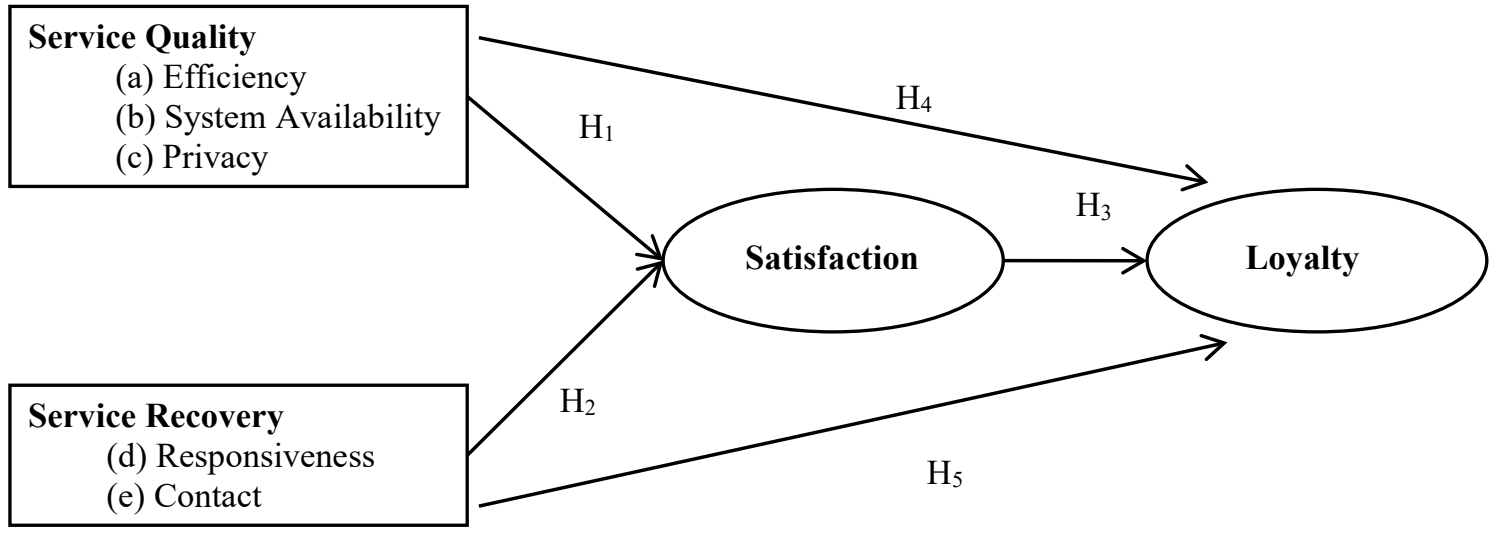

\section{RESEARCH METHODOLOGY}

\subsection{Questionnaire and measures}

To test the above hypotheses, an empirical study was conducted with a sample of Spanish customers of online banks. This study thus attempts to reassess the applicability of the e-SQ scales as proposed by Parasuraman et al. (2005) in a non-retail context such as financial services, which have fewer tangible elements representing the main difference between products and services in a tangible spectrum (Ladarhi, 2010). A structured questionnaire was designed specifically for the study. The construct of 'e-service quality', 'e-service recovery' was measured using an adapted version of the original E-S-QUAL and E-RecS-Qual scale (Parasuraman et al., 2005). The construct of 'loyalty' was also adopted from Parasuraman et al. (2005) and the construct of 'esatisfaction' was evaluated using four items adopted from Ribbink et al. (2004) with minor alterations.

All items were assessed on a five-point Likert-type scale $(1=$ 'strongly disagree'; $5=$ 'strongly agree'). 


\subsection{Sampling and data collection}

The sample was derived from a database maintained by Spanish banks. Online banking users were selected by choosing a random starting point and choosing every fiftieth individual customer in succession thereafter. This technique yielded 1,600 potential respondents, who were invited by email to participate in the survey and were directed to a specific website containing the structured questionnaire, which they then self-administered. Data collection was completed in May 2010. After scanning some incomplete or invalid questionnaires, 428 valid completed questionnaires representing a response rate of $26.75 \%$.from Spanish customers of e-banking were retained;

\section{DATA ANALYSIS AND RESULTS}

\section{1 demographic characteristics}

A summary of the demographic characteristics of the respondents in the study shows that no gender bias was detected. Two-thirds of the respondents were aged less than 34 years. The educational level of the sample was high, with more than two-thirds of the sample having a university degree. A large majority (65.9\%) of the respondents earned an annual income of less than $€ 24,000$. Encouragingly, two-thirds of the respondent had used e-banking in the preceding week. Recent events and evaluations are especially powerful because they are more accessible and more "silent", and thus easier to retrieve from memory (Oliver, 2010)

The demographic characteristics of the sub-sample of the individuals who complained or experienced problems in the service received indicate no gender bias, half of the respondents were aged less than 34 and the educational level was high, with two thirds of the sub sample having a bachelor's or a master's degree.

A comparison of means among the two independent samples (those individuals who did not report any problems and those who encountered a problem) was conducted using the Wilcoxon-Mann-Whitney test. Four contrasts were assessed between the two groups, assuming a null hypothesis that there was no difference of means between the groups. The results show no 
differences detected in terms of gender and education. However, there were slight differences $(10 \%)$ between respondents age 17-23 $(\mathrm{P}<0.05)$ and annual income less than $12,000(\mathrm{P}<0.05)$.

Significant differences were detected regarding age and annual income. It was thus apparent that those who experienced problems are in the higher age categories and also have higher annual incomes. The profile of the sample was comparable to the total population of bank customers in Spain. It appears not to be a surprise as the data profile of this particular group indicates that they were likely to be students (Marimon et al., 2012)

\section{RESULTS}

Exploratory factory analysis was conducted on the items in the amended E-S-QUAL and E-RecS-QUAL scale using normalized varimax as the rotation method (Hair et al., 1998). The Kaiser-Meyer-Olkin (KMO) measures were 0.935 and 0.847 . Bartlett's sphericity tests were $5,125.3(\mathrm{df}=171)$ and $347(\mathrm{df}=21)$ with a significance of 0.000 . In addition $64.11 \%$ and $69.6 \%$ of variance accounted for the modified E-S-QUAL and E-RecS-Qual respectively. Consequently all variables were kept in the model and both the measurement scales and the proposed structural model were estimated by means of Partial Least Squares (PLS version 2.0). PLS makes no assumptions regarding the distribution of the variables and ensures optimal prediction accuracy (Fornell and Cha., 1994). It has special capabilities that make it more appropriate than other techniques when analyzing small sample sizes, and it is shown to be very robust against multicollinearity (Cassel et al., 2000).

\subsection{Evaluation of measurement scales}

Given that global measurement of website service quality is difficult to develop and is likely to be subject to the same criticisms confronting the SERVQUAL scale (for the global measurement of service quality), i.e., that of being dependent on a specific industry or context (Yang et al., 2004). Therefore, even though the items used to measure the constructs in this study 
were based on items from the extant literature, it was necessary to check their validity in the current context by conducting tests to evaluate the reliability of individual items, internal consistency, convergent validity, and discriminant validity (Petnji et al., 2012).

The satisfactoriness of the measurement scales was first assessed by evaluating the reliability of the individual items. As shown in Table 1, the loadings of items on their respective constructs revealed a high degree of individual item reliability, as all items have loadings of greater than 0.5 in their respective constructs (Sanzo et al., 2003). Individual item reliability refers to the loadings or simple correlations of the indicators with their respective latent variable (Ledden et al., 2007). These authors are more demanding criteria than Sanzo. Nevertheless we follow Sanzo, because this is still an exploratory study in this particular setting.

The validity of individual items in relation to the relevant factors was confirmed by load values greater than 0.707 (Carmines \& Zeller, 1979), with the exception of item 'EFF 5', which was slightly lower. However, because it was so close to the threshold, it was decided to retain this item, in accordance with the relaxed criterion suggested by Barclay et al. (1995).

In addition, the scales dimensionality of the modified E-S-QUAL and E-RecS-Qual confirmed the validity of three factors for the evaluation of Service Quality and two factors for the evaluation of Service Recovery. A considerable degree of internal consistency and reliability (that provides an assessing of internal homogeneity of a set of items) in all dimensions was confirmed, since the Cronbach's alpha for the constructs ranged from 0.77 ('Contact') to 0.91 ('Satisfaction'), which exceeded the generally accepted minimum level of 0.7 (Nunnally \& Bernstein, 1994). The average variance extracted (AVE) for every scale was greater than the recommended value of 0.5 (Fornell and Larcker, 1981), and each individual item's coefficient was more than double the value of its standard error, indicating that the items represent their underlying construct. Altogether, this provides evidence of a high degree of convergent validity.

\section{Table 1: Loads on the Exterior model}

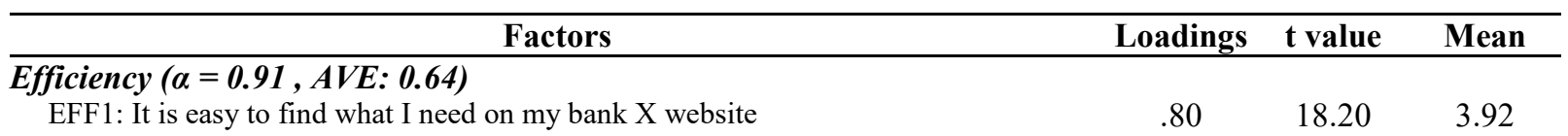


EFF2: It is easy to access anywhere on my bank $\mathrm{X}$ site

$\begin{array}{lll}.80 & 18.77 & 3.95 \\ .72 & 11.30 & 4.01 \\ .83 & 24.10 & 3.81 \\ .81 & 16.52 & 3.92 \\ .76 & 14.80 & 4.08 \\ .86 & 34.00 & 3.83 \\ & & \\ .73 & 11.38 & 4.01 \\ .85 & 24.34 & 3.96 \\ .78 & 14.75 & 3.89 \\ .77 & 14.36 & 3.96 \\ .76 & 15.74 & 4.15 \\ .82 & 23.60 & 4.07 \\ .67 & 7.57 & 3.88 \\ & & \\ .89 & 27.26 & 4.17 \\ .90 & 24.86 & 4.21 \\ .92 & 45.47 & 4.26\end{array}$

EFF4: Information at this site is well organized

EFF6: This site is simple to use.

EFF7: This site enables me to get on to it quickly.

3.92

EFF8: This site is well organized.

System Availability ( $\alpha=0.89$, AVE: 0.60$)$

SAV1: This site is always available for business.

SAV2: This site launches and runs right away

SAV4: Pages at my bank X site do not freeze after I enter my order information

FUL1: It carries out orders when they have been validated

FUL2: It quickly delivers what I order.

Privacy $(\alpha=0.89$, AVE: 0.82)

PRII: My bank X website protects information about my online banking behavior

$\begin{array}{lll}.90 & 7.97 & 3.59\end{array}$

\section{Loyalty $(\alpha=0.90$, AVE: 0.71)}

LOY1: Say positive things about this online banking site to other people. LOY2: Recommend this online banking site to someone who seeks your advice.

LOY3: Encourage friends and others to do business with this site.

LOY4: Consider this online banking site to be your first choice for fin

\section{Satisfaction ( $\alpha=0.92$, AVE: 0.80$)$}

ESA1: I am generally pleased with Bank X's online services.

ESA2: The website of this online bank $X$ is enjoyable to use.

\begin{tabular}{lll}
.89 & 34.41 & 4.08 \\
.83 & 19.07 & 3.85 \\
.92 & 49.71 & 3.92 \\
.92 & 49.70 & 3.99 \\
\hline
\end{tabular}

ESA3: I am very satisfied with this bank X's online services. ESA4: I am happy with this online bank X.

$\alpha$ : Cronbach's alpha; AVE: Average Variance Extracted.

Additionally, each possible correlation between pair constructs was assessed. The square root of the AVE was greater than the correlations presented by each construct with other constructs (Fornell and Larcker, 1981). Besides, correlation coefficients were less than 1 by an amount more than double its respective standard error (Ribbink et al., 2004) (see Table 2). Taken as a whole, this evidence supported the discriminant validity of the items as measures of their respective underlying constructs.

Table 2: Descriptive and bivariate correlations between main constructs, and the square root of Average Variance Extracted 


\begin{tabular}{lccccccccc}
\hline & Mean & SD & $\mathbf{1}$ & $\mathbf{2}$ & $\mathbf{3}$ & $\mathbf{4}$ & $\mathbf{5}$ & $\mathbf{6}$ & $\mathbf{7}$ \\
\hline 1. Efficiency & 3.93 & .70 & $\mathbf{. 8 0}$ & & & & & & \\
2. System availability & 3.99 & .67 & .68 & .77 & & & & & \\
3. Privacy & 4.21 & .80 & .48 & .53 & $\mathbf{. 9 0}$ & & & & \\
4. Responsiveness & 3.09 & .95 & .32 & .28 & .22 & $\mathbf{. 8 1}$ & & & \\
5. Contact & 3.67 & .98 & .21 & .16 & .21 & .54 & $\mathbf{. 8 2}$ & & \\
6. Satisfaction & 3.95 & .76 & .62 & .69 & .66 & .36 & .26 & $\mathbf{. 8 9}$ & \\
7. Loyalty & 3.58 & .89 & .60 & .55 & .49 & .44 & .27 & .68 & $\mathbf{. 8 4}$
\end{tabular}

Notes: The square roots of AVE are in bold Italic font style on the main diagonal and the correlations between latent variables follow below; All correlations were significant at the 0.01 level (two-tailed)

\subsection{Hypothesis testing of the conceptual model}

A structural path representing relationships between different constructs was examined. The index of variance for endogenous variables explained by the path was more than 0.015 . The fit indices of individual $\mathrm{R}^{2}$ was more than 0.50 and the model explained was more than half of the variance of each independent variable (see Table 3). Furthermore the goodness-of-fit index, which takes into account both the explained variances for latent dependent variables and their communality, was significant $(\mathrm{GoF}=0.68)$ as proposed by Tenenhaus et al. (2004). A plinth in the statistical performance model, it can be assumed that the proposed model exhibited a good fit to the data, and the hypothesized relationships were tested.

Table 3: Model fitness

\begin{tabular}{|l|c|c|c|c|c|c|}
\hline & AVE & $\begin{array}{c}\text { Composite } \\
\text { Reliability }\end{array}$ & R Square & $\begin{array}{c}\text { Cronbach's } \\
\text { Alpha }\end{array}$ & Communality & Redundancy \\
\hline Contact & & & & & & \\
\hline Efficiency & 0.68 & 0.86 & & 0.77 & 0.68 & \\
\hline Loyalty & 0.64 & 0.93 & & 0.91 & 0.64 & \\
\hline Privacy & 0.71 & 0.92 & 0.57 & 0.90 & 0.71 & -0.00 \\
\hline Responsiveness & 0.82 & 0.93 & & 0.89 & 0.82 & \\
\hline Satisfaction & 0.80 & 0.94 & 0.69 & 0.92 & 0.80 & 0.01 \\
\hline
\end{tabular}




\begin{tabular}{|l|l|l|l|l|l|l|}
\hline System Availability & 0.60 & 0.91 & & 0.89 & 0.60 & \\
\hline
\end{tabular}

The significance of the paths of the inner model was calculated by using bootstrapping based on 1,000 resamples to determine the steadiness and the statistical significance of the factor estimates. Table 4 summarizes the results of the hypothesis testing. Overall results show all the hypotheses were supported except the "contact" dimension, which had no direct effects $(\mathrm{P} \geq 0.05)$ on loyalty and satisfaction. As expected, hypothesis H3, predicting the positive impact of satisfaction on loyalty, is significantly supported. Furthermore hypotheses $\mathrm{H} 1$ and H4, predicting a positive influence of perceived online service quality on satisfaction and loyalty, were specifically supported, since all three online service quality dimensions are significantly related to customer loyalty and satisfaction. Conversely, H2 and H5 were partially supported as the double interaction between "responsiveness", while "contact" on "satisfaction" and "loyalty" produced surprising results in the form of an insignificant positive effect of "contact" on "loyalty" and "satisfaction". Instead, we found that service recovery directly influence customer loyalty and satisfaction quite independently, through responsiveness as the focal predictor.

In addition the squared multiple coefficient for online satisfaction is $68.9 \%(\mathrm{p}<.000)$, showing that a large segment of variation in online satisfaction is accounted for by online service quality and online service recovery. As we had suggested, then, we tested the indirect effects of service quality and recovery on loyalty through online satisfaction. The mediation effects were assessed using the bootstrapping method, thus providing a way to overcome the limitations of statistical methods that make assumptions about the shape of sampling distributions, viewed in terms of concepts such as normality. Moreover, the measures and tests of the direct effects can address mediation more directly than a series of separate significance tests not directly involving the indirect effect found in the mediation model (Preacher and Hayes, 2004). The results indicated that online satisfaction strongly depended on the effects of "system availability", "privacy" and "contact", while the indirect effects of efficiency and responsiveness on loyalty were also significant. Meanwhile their direct effects remained significant, demonstrating that customer 
satisfaction partially exerted its influence on customer loyal. Overall the mediating roles were supported, i.e., customer satisfaction will depend on the effects of perceived online service quality, and online service recovery will depend on customer Loyalty.

Table 4: Hypothesis results for the Structural Model

\begin{tabular}{|c|l|c|c|c|c|c|}
\hline \multicolumn{2}{|c|}{ Hypothesis } & $\begin{array}{c}\text { Path } \\
\text { coefficient }\end{array}$ & SE & t-value & P-value & Conclusion \\
\hline H1a & Efficiency $\rightarrow$ Satisfaction & 0.37 & 0.04 & 7.07 & 0.000 & Accepted*** \\
\hline H1b & $\begin{array}{l}\text { System availability } \rightarrow \\
\text { Satisfaction }\end{array}$ & 0.24 & 0.04 & 3.58 & 0.000 & Accepted*** \\
\hline H1c & Privacy $\rightarrow$ Satisfaction & 0.33 & 0.03 & 10.56 & 0.000 & Accepted*** \\
\hline H2d & Responsiveness $\rightarrow$ Satisfaction & 0.10 & 0.03 & 2.87 & 0.004 & Accepted*** \\
\hline H2e & Contact $\rightarrow$ Satisfaction & 0.02 & 0.03 & 0.67 & 0.504 & Rejected \\
\hline H3 & Satisfaction $\rightarrow$ Loyalty & 0.51 & 0.05 & 9.51 & 0.000 & Accepted*** \\
\hline H4a & Efficiency $\rightarrow$ Loyalty & 0.13 & 0.05 & 7.07 & 0.000 & Accepted*** \\
\hline H4b & System availability $\rightarrow$ Loyalty & 0.02 & 0.04 & 3.58 & 0.000 & Accepted*** \\
\hline H4c & Privacy $\rightarrow$ Loyalty & 0.04 & 0.04 & 5.25 & 0.000 & Accepted*** \\
\hline H5d & Responsiveness $\rightarrow$ Loyalty & 0.20 & 0.04 & 6.32 & 0.000 & Accepted*** \\
\hline H5e & Contact $\rightarrow$ Loyalty & -0.00 & 0.04 & 0.03 & 0.976 & Rejected \\
\hline
\end{tabular}

a: Standard Error; Significant at two tail: ${ }^{(*)} \mathrm{P}$-value $<0.05 ;{ }^{(* *)} \mathrm{P}$-value $<0.01$ and ${ }^{\left({ }^{* *}\right)} \mathrm{P}$-value $<0.001$

\section{CONCLUSIONS AND MANAGERIAL IMPLICATIONS}

This study contributes to and extends a growing research stream documenting the scale evaluation of e-SQ. The results provide acceptable psychometric measures for reliability and validity tests of the amended E-S-QUAL and E-RecS-QUAL scales. Accordingly, efficiency, system availability and privacy can be taken as suggested by Petnji et al., (2012) as the underlying dimensions of perceived online service quality; and responsiveness and contact as the underlying dimensions of electronic service recovery in a non-retail context such as online financial services, education, tourism, employment agencies, etc.

Previous researchers have acknowledged the vital role of customer satisfaction in a variety of customer behavior models. However, in terms of electronic service providers, rarely researches have been conducted into the simultaneous role of both online service quality and service recovery 
and into which is the more important role between the two, together with the contributory role of customer satisfaction in relation to online loyalty.

With empirical data and thorough statistical testing, this study found that antecedents such as perceived online service quality, recovery and satisfaction can be used to promote customer loyalty. The dimensions of "efficiency", "privacy", "system availability" and "responsiveness" have direct/indirect significant and positive effects on customer satisfaction and loyalty, with "efficiency" and "privacy" being the most important predictors.

However it is more important to increase customer satisfaction, which requires an external focus on developing what will "go right" in the first place by enhancing perceived online service quality, instead of preventing dissatisfaction through recovery, which is an internal focus on fixing what has "gone wrong" (Dahlsten, 2003)

From a management perspective, a clear understanding of the sequences in the relationships between service quality, recovery, satisfaction and, ultimately, customer loyalty can help identify customers that have the highest potential for defection and which can best ensure better strategy of customer loyalty, which could in turn have considerable marketing implications.

In terms of practice, the findings of this study provide a number of practical implications for e-business managers. In the first instance, given the fact that "efficiency" and "privacy" are identified as the important key dimensions in e-SQ in predicting both customer satisfaction and customer loyalty, online retailers and electronic service provider managers must ensure that sufficient information on the desired product and services such as price, guarantee, return policy etc. should be easy to find and understand. We also recommend that they ensure that their website has an uncluttered look and provide the service they promise accurately and on time.

The security and protection of customers' personal information such as credit card details has become a factor of paramount for e-business customer. Managers should provide explicit and reassuring guarantee that transactions on their website are processed with some kind of site safe program. Also, the site must provide meaningful guarantee that all personal and transactional information are transmitted over a secure encrypted server which protects personal information continuously. Furthermore, customer must be aware of the types of information the site collect, 
how they are used and under what circumstances. In addition, a firm guarantee that personal information is not disclosed to a third party may also enhance customer perception of privacy dimension, hence, improve customer satisfaction and customer loyalty.

Moreover, system availability was placed in the middle level of customers' appreciation of factors that may directly/indirectly influence customer satisfaction and customer loyalty, while responsiveness was perceived as the least performed. Therefore, managers must look closely at the correct functioning of the website and the ability to swiftly fulfill the promised service reliably and correctly. Besides, managers must effectively handle problems and return through the website, by responding promptly and accurately to all enquiries and customers' encounters. Besides, they must ensure their contact e-mail is always available as well as the correct functioning of their e-mail system endlessly.

At last, we emphasize that what is really important is providing quality rather than recovering when a failure has occurred. The findings of the paper provide clues to practitioners when they have to choose the projects in which to invest. Improving e-quality yields a bigger impact on loyalty than e-recovery.

This study contributes and extends a growing research stream documenting the scale

Overall, managers should ensure that their level of service deliver on their website meets or exceeds the level of service expected by their customers. Additionally, the main emphasis of management plan should be on improving customer satisfaction, which will in turn enhance loyalty. Clear evidence was provided indicating that service quality and service recovery robustly affects customer satisfaction more than loyalty. Yet, it is the contention of the present study that managers must make sure they delight their customers in the first place by offering superior service quality at the outset, instead of merely preventing dissatisfaction through service recovery.

\section{REFERENCES}

Akinci, S., Atilgan-Ina, E. and Aksoy, S. (2010) "Re-assessment of E-S-Qual and E-RecS-Qual in a pure service setting” Journal of Business Research, 63, pp. 232-240. 
Anderson, R. E. \& Srinivasan, S. S. (2003). E-satisfaction and E-loyalty: A Contingent Framework, Psychology \& Marketing, 20(2), 123-138.

Barclay. D.; Higgins. C.; Thompson. R. (1995): “The Partial Least Squares (PLS) Approach to Causal Modelling: Personal Computer Adoption and Use as an Illustration”. Technology Studies. (Special Issue on Research Methodology). Vol. 2. N² 2. pp. 285-309.

Berry, L.L. and Parasuraman, A. (1991), Marketing Services: Competing through Quality, The Free Press, New York, NY.

Bloemer, J., de Ruyter, K. and Wetzels, M. (1999), "Linking perceived service quality and service loyalty: a multi-dimensional perspective”, European Journal of Marketing, Vol. 33 Nos 11/12, pp. 1082-107.

Boshoff, C. (2005), “A re-assessment and refinement of RECOVSAT: An instrument to measure satisfaction with transaction-specific service recovery", Managing Service Quality, 15(5), $410-425$.

Boshoff, Christo (2007), “A psychometric assessment of E-S-QUAL: a scale to measure electronic service quality", Journal of Electronic Commerce Research, Vol. 8, No. 1, pp.101-114.

Carmines. E.G.; Zeller. R.A. (1979): Reliability and Validity Assesment. (Stage University Paper Series on Quantitative Applications in the Social Sciences. $\left.\mathrm{n}^{\circ} .7010\right)$. Beverly Hills. CA: Sage.

Caruana, A. (2002). Service Loyalty: The Effects of Service Quality and the Mediating role of Customer Satisfaction. European Journal of Marketing, 36(7), 811-828.

Cassel, C.M., Hackl, P. and Westlund, A.H. (2000), "On measurement of intangible assets: a study of robustness of partial least squares", Total Quality Management, Vol. 11 No. 7, pp. S897-S907.

Ching-Fu Chen and Lee-Ting Cheng (2012) "A study on mobile phone service loyalty in Taiwan" Total Quality Management \& Business Excellence, Volume 23, Issue 7-8, pp 807-819. 
Chiou J. S., (2003) "The antecedents of consumers' loyalty toward Internet Service Providers" Information \& Management 41 (2004) 685-695.

Cronin, J.J. and Taylor, S.A. (1992), "Measuring service quality: a reexamination and extension”, Journal of Marketing, Vol. 56, July, pp. 55-68.

Estelami, H. (2000), "Competitive and procedural determinants of delight and disappointment on consumer complaint outcomes”, Journal of Service Research, Vol. 2 No. 3, pp. 285-300.

Formell, C. (1992): “A National Customer Satisfaction Ba-rometer the Swedish Experience". Journal of Marketing. 56 (January), pp. 6-21.

Fornell, C. and Cha, J. (1994), "Partial least squares", in Bagozzi, R.P. (Ed.), Advanced Methods of Marketing Research, Blackwell, Oxford, pp. 52-78.

Fornell. C. \& Larcker. D.F. (1981). Evaluating structural equation models with unobservable variables and measurement error. Journal of Marketing Research. 28(1). 39-50.

Fredrik Dahlsten, 2003, "Avoiding the Customer Satisfaction Rut" MIT Sloan Management Review, Volume 44, Number 4, pages 73-77

Harris, L.C. and M.M. H. Goode, The Four Levels of Loyalty and the Pivotal Role of Trust: a Study of Online Service Dynamics, Journal of Retailing, Vol.80, 2004, pp.139-158.

Hsin Hsin Chang, Chin-Ho Lee and Chi-Yuan Lai (2012), "E-Service quality and relationship quality on dealer satisfaction: Channel power as a moderator" Total Quality Management \& Business Excellence, Volume 23, Issue 7-8, pp 855-873.

Ledden, L., Kalafatis, S., Samouel, P. (2007), “The relationship between personal values and perceived value of education”, Journal of Business Research, Volume 60, 965-974.

Marimon, F.; Vidgen, R.; Barnes, S.; Cristobal, E., 2010, "Purchasing behaviour in an online supermarket: the applicability of E-S-QUAL" , International Journal of Market Research, $52, \mathrm{n}^{\mathrm{o}} 1,111-129$.

Marimon, F., Petnji, L. \& Casadesus, M. (2012), Impact of e-Quality and service recovery on loyalty: A study of e-banking in Spain, Total Quality Management \& Business Excellence, Volume 23, Numbers 7, pp. 769-787. 
Meng, Juan, (2010): “Measurement Equivalency of Web Service Quality Instruments: A Test on Chinese and African American Consumers" Journal of International Consumer Marketing, 1528-7068, Volume 22, Issue 3, 2010, Pages 259- 269.

Meuter. M.L., Ostrom. A.L., Roundtree. R.I. \& Bitner. M.J. (2000). Self-service technologies: Understanding customer satisfaction with technology-based service encounters. Journal of Marketing. 64(3). 50-64.

Michael A. McCollough, Leonard L. Berry and Manjit S. Yadav, 2000, "An Empirical Investigation of Customer Satisfaction after Service Failure and Recovery" Journal of Service Research, 3: 121-137

Nunnally, J. C. and Bernstein, I. H. (1994), Psychometric Theory, McGraw-Hill. New York.

Oliver, R.L., 1993. A conceptual model of service quality and service satisfaction: compatible goals, different concepts. Advances in Services Marketing and Management 2, 65-85.

Oliver, R.L., 2010. Satisfaction: A Behavioral Perspective on the Consumer (Second Edition). Armonk, N.Y.: M.E. Shape.

Parasuraman, A., Zeithaml, V. A., \& Berry, L. L. (1988). SERVQUAL: A Multiple-Item Scale for Measuring Consumer Perceptions of Service Quality. Journal of Retailing, 64(1), 1240.

Parasuraman, A., Zeithaml, V. A., \& Malhotra, A. (2005). E-S-QUAL: A Multiple-Item Scale for Assessing Electronic Service Quality. Journal of Service Research, 7(3), 213-233.

Petnji, Y.L.H., Marimon, F., Casadesus, M. (2011), Customer's loyalty and perception of ISO 9001 in online banking. Industrial Management \& Data System. Vol: 111, Iss: 8

Petnji Yaya, L.H., Marimon, F. \& Casadesus Fa, M. (2012), Assessing e-service quality: the current state of E-S-QUAL. Total Quality Management \& Business Excellence, 23(12), $1363-1378$.

Preacher, K. J., \& Hayes, A. F. (2004). SPSS and SAS procedures for estimating indirect effects in simple mediation models. Behavior Research Methods, Instruments, and Computers, 36, $717-731$. 
Reichheld, F.F., \& Schefter, P. (2000). E-loyalty: Your secret weapon on the web. Harvard Business Review, 87(4), 105-113.

Ribbink, D., van Riel,, A. and Streukens, S. (2004), “Comfort your online customer: quality, trust and loyalty on the internet", Managing Service Quality, Vol. 14, No. 6, pp. 446-456.

Richard A. Sprenc; Robert D. Mackoy, “An Empirical Examination of a Model of Perceived Service Quality and Satisfaction” Journal of Retailing volume 72, Issue 2, Summer 1996, pages 201-214

Rui Sousa and Chris Voss (2012), "The impacts of e-service quality on customer behaviour in multi-channel e-services" Total Quality Management \& Business Excellence, Volume 23, Issue 7-8, pp 789-806

Sanzo. M.J.. Santos. M.L.. Vázquez. R.. and Álvarez. L.I. (2003) “The effect of market orientation on buyer-beller relationship satisfaction”. Industrial Marketing Management. Vol. 32. No. 4. pp. 327-345.

Tax, Stephen Saul, Stephen W. Brown, Murali Chandrashekaran. 1998. Customer evaluations of service complaint experiences: Implications for relationship marketing. /. Marketing 62(2) $60-76$.

Tenenhaus, M., Amato, S., and Esposito Vinzi, V. (2004). A global goodness-of-fit index for PLS structural equation modelling. Proceedings of the XLII SIS Scientific Meeting, Vol. Contributed Papers, CLEUP, Padova, pp. 739-742.

Wen-Bao Lin (2012) “The determinants of consumers' switching intentions after service failure" Total Quality Management \& Business Excellence, Volume 23, Issue 7-8, pp 837-854

Yang, Z., Cai, S., Zhou, Z., Zhou, N. (2004) "Development and validation of an instrument to measure user perceived service quality of information presenting Web portals" Information \& Management 42 (2005) 575-589

Yi-Hui Liang (2012), "Exploring the relationship between perceived electronic service quality, satisfaction, and personality: a study of Taiwan's online game industry" Total Quality Management \& Business Excellence, Volume 23, Issue 7-8, pp 949-963 
Zeithaml, V.A., Bitner, M.J., 2000. Services Marketing: Integrating Customer Focus Across the Firm. McGraw-Hill, New York.

Zeithaml. V.A.. Parasuraman. A. \& Malhotra. A. (2002). Service quality delivery through web sites: A critical review of extant knowledge. Journal of the Academy of Marketing Science. 30(4). 362-375. 